\title{
Benthic mineralization and exchange in Arctic sediments (Svalbard, Norway)
}

\author{
Ronnie Nøhr Glud*, Ola Holby, Friederike Hoffmann, Donald E. Canfield**
}

Max Planck Institute for Marine Microbiology, Celsius Str. 1, D-28359 Bremen, Germany

\begin{abstract}
By means of benthic landers, sediment core incubations and the whole core squeezing (WCS) technique, benthic exchange and mineralization rates were investigated in 4 different fjords of Arctic Norway (Svalbard). These coastal sediments experience constant low temperatures close to $0^{\circ} \mathrm{C}$. The sediments were dominated by large densities of bioirrigating macrofauna, which enhanced the benthic in situ $\mathrm{O}_{2}$ uptake by a factor of 1.8 to 2.9 over the diffusive mediated uptake. Recovered sediment cores significantly underestimated the in situ solute exchange rate, presumably due to exclusion of fauna. Faunal activity in situ additionally resulted in a complex sediment structure, which created a smearing of chemical profiles when applying the WCS technique. The benthic exchange rates of dissolved inorganic carbon determined in situ varied between 9 and $20 \mathrm{mmol} \mathrm{m} \mathrm{m}^{-2} \mathrm{~d}^{-1}$ at the different stations. Denitrification was of minor importance for benthic mineralization, and the $\mathrm{C} / \mathrm{N}$ ratio of the effluxing inorganic solutes was close to 10 , indicating that relatively fresh organic material was mineralized. The sediment accumulation rate was estimated from ${ }^{210} \mathrm{~Pb}$ profiles to be in the range of 1.3 to $5.9 \mathrm{~mm} \mathrm{yr}^{-1}$ Assuming that our estimated mineralization rates approach the yearly average, it was calculated that 31 to $47 \%$ of the organic carbon reaching the sediment surface was permanently buried. Benthic mineralization rates and carbon burial rates were similar to those obtained in coastal sediments of temperate and tropical regions. This indicates that benthic communities in Arctic sediments rather than being limited by low temperatures are limited by carbon availability
\end{abstract}

KEY WORDS: Carbon · Oxygen · Microsensors · Benthic mineralization · Landers · Burial

\section{INTRODUCTION}

Even though the shelf and coastal zone accounts for less than $10 \%$ of the total ocean area it accounts for more than $30 \%$ of the total oceanic primary production (Berger et al. 1989). It is estimated that 25 to $50 \%$ of the water-column production in shallow areas settles to the sediment surface (Wollast 1991). A significant part of this material becomes reoxidized, mainly by different populations of microorganisms, while the remainder is permanently buried (Berner 1980, Canfield 1989). Coastal sediments thereby play an important role in recycling nutrients and carbon for continued

\footnotetext{
Present addresses:

- Marine Biological Laboratory, University of Copenhagen, Strandpromenaden 5, DK-3000 Helsingor, Denmark.

E-mail: mblrg@mail.centrum.dk

- Institute of Biology, University of Odense, Campusvej 55, DK-5230 Odense M, Denmark
}

primary production in the water column, but, simultaneously, they act as globally important nitrogen and carbon sinks. There exists a vast body of literature exploring the rates of benthic mineralization, and the quantitatively most important electron acceptors have been identified as $\mathrm{O}_{2}, \mathrm{NO}_{3}, \mathrm{Mn}$ oxides, $\mathrm{Fe}$ oxides and $\mathrm{SO}_{4}{ }^{2-}$ (e.g. Jørgensen 1977, Bender \& Heggie 1984, Canfield et al. 1993). Despite these many studies little is known about the importance of benthic coastal mineralization in permanently cold Arctic environments (Pfannkuche \& Thiel 1987, Grebmeier \& McRoy 1989, Grant et al. 1991, Hulth et al. 1994, Piepenburg et al. 1995, Rysgaard et al. 1996)

The Arctic region is characterized by a large interseasonal variation in water-column production, where primary and secondary production increase as the light availability increases and the ice cover melts. The yearly primary production of many Arctic areas is surprisingly high considering the low temperatures and 
the seasonal ice cover (Sambrotto et al. 1984, Subba Rao \& Platt 1984). This includes the Barents Sea and the fjords of Svalbard, where the average yearly primary production has been estimated to be on the order of 115 to $165 \mathrm{~g} \mathrm{C} \mathrm{m}^{-2} \mathrm{yr}^{-1}$ (Eilertsen et al. 1989, Sakshaug \& Slagstad 1992). This is comparable to estimates for many temperate coastal areas (Wollast 1991, Antoine et al. 1996). Given a tight pelagic-benthic coupling for high latitude areas (Wassmann 1990, Wasmann et al. 1991), high benthic mineralization and/or carbon burial rates in the fjords of Svalbard could be expected.

A common technique to estimate total benthic mineralization is to quantify benthic $\mathrm{O}_{2}$ consumption, since $\mathrm{O}_{2}$ acts as an electron acceptor both in the aerobic heterotrophic metabolism and in oxidation of the reduced solutes originating during anaerobic mineralization (e.g. Smith \& Hinga 1983). Alternatively, the total benthic release of dissolved inorganic carbon (DIC), the ultimate product from organic carbon mineralization, is used as a measure of the total mineralization (e.g. Hall et al. 1990). The exchange of solutes across the sediment-water interface can be measured on recovered sediment cores (e.g. Jørgensen 1977) or in situ using benthic landers (e.g. Smith et al. 1983). Both in situ and laboratory incubations measure the net exchange rates of solutes across the sedimentwater interface, but provide limited information about the processes occurring within the sediment. From porewater profiles it is, however, in some cases possible to identify zones of consumption and production of reduced and oxidized species. Further, from porewater profiles it is possible to calculate the diffusional flux of solutes across the sediment-water interface (e.g. Berner 1980).

In the following we quantify benthic exchange and mineralization rates in 4 fjords of Arctic Norway (Svalbard). Rates were estimated from (1) $\mathrm{O}_{2}$ microprofiles measured in situ and in the laboratory, (2) porewater profiles obtained by whole core squeezing (WCS) and (3) total benthic exchange measurements performed in situ and in the laboratory. Data obtained by the various techniques are compared and the efficiency and importance of benthic mineralization in these permanently cold areas are discussed.

\section{MATERIALS AND METHODS}

Study area. Five stations around Svalbard and northern Norway were visited in the period 10 to $25 \mathrm{Sep}$ tember 1995, with the Norwegian research vessel 'Jan Mayen'. Stn SV-1 was close to the mainland in Malangen. Three stations were located in 2 fjords on the west side of Svalbard (Van Mijen Fjord [SV-3] and Horn- sund [SV-2 and SV-4]) while the last station was located in Storfjorden (SV-5) (Fig. 1). Station characteristics are listed in Table 1. While the fjords of western Svalbard are kept relatively warm by the west Spitsbergen current, the fjords of eastern Svalbard are characterized by very low temperatures. During the cruise the bottom-water temperatures of the fjords on the west side of Svalbard were between +0.2 and $+2.8^{\circ} \mathrm{C}$, but in Storfjorden on east Svalbard the temperature was only $-1.7^{\circ} \mathrm{C}$. The fjords of Svalbard are ice-covered in the winter period with a well-mixed water column. However, in April-May ice melting stabilizes the water column, which together with increased light availability typically initiates a spring bloom. During summer smaller blooms may follow, depending on the hydrography and the nutrient balance. For each station (except SV-1) the total benthic exchange of $\mathrm{O}_{2}, \mathrm{DIC}, \mathrm{NH}_{4}{ }^{+}, \mathrm{NO}_{3}{ }^{-}$and $\mathrm{Mn}^{2+}$, and $\mathrm{O}_{2}$ microprofiles were measured in situ as well as in the laboratory. Denitrification rates and WCS profiles of $\mathrm{O}_{2}, \mathrm{DIC}, \mathrm{NH}_{4}{ }^{+}$and $\mathrm{NO}_{3}{ }^{-}$were measured in the laboratory.

In situ measurements. The 2 benthic landers 'Elinor' and 'Profilur' were deployed in order to measure benthic exchange rates and $\mathrm{O}_{2}$ microprofiles (Gundersen \& Jørgensen 1990, Glud et al. 1994a).

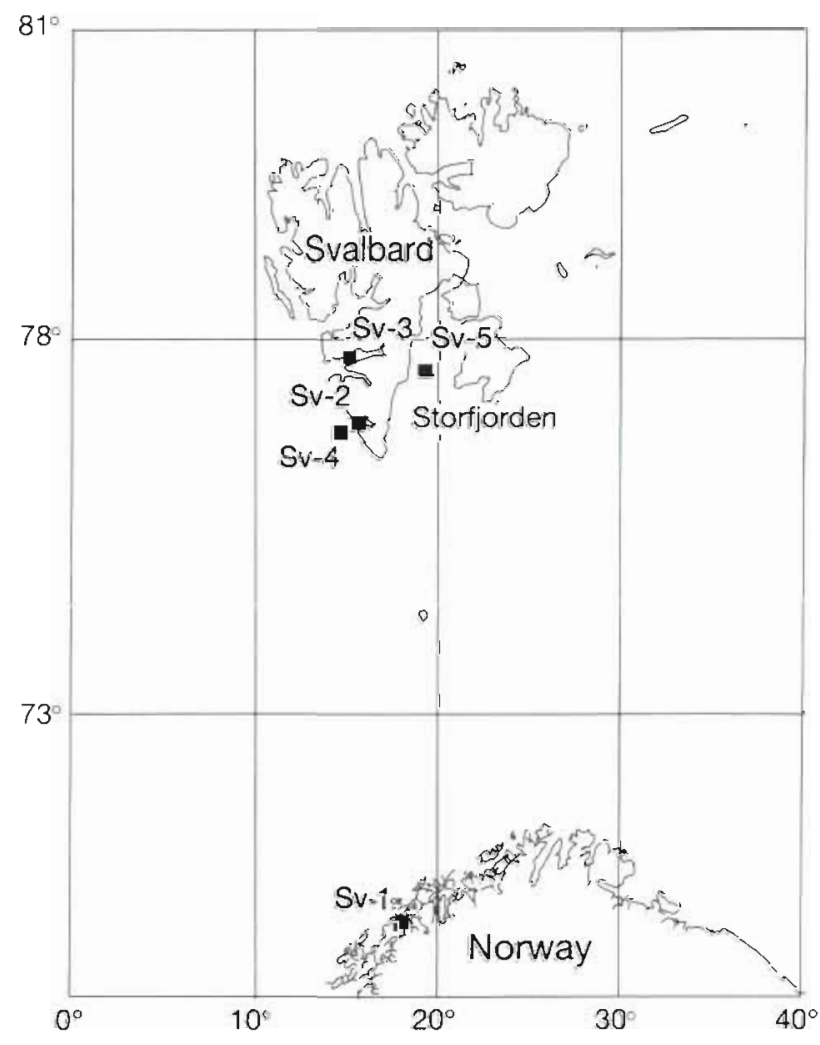

Fig. 1. Map of Svalbard including northern Norway. The positions of the single sites are indicated 
Table 1. Position, water depth, bottom-water (BW) temperature, bottom-water oxygen concentration, bottom-water nitrate concentration and fauna (LOI: loss on ignition) of stations around Svalbard and northern Norway used in this study. $\mathrm{nm}$ : not measured

\begin{tabular}{|lccccc|}
\hline & SV-1 & SV-2 & SV-3 & SV-4 & SV-5 \\
\hline Position & & & & & \\
$\quad$ Latitude & $69^{\circ} 29.4^{\prime} \mathrm{N}$ & $76^{\circ} 58.2^{\prime} \mathrm{N}$ & $77^{\circ} 45.8^{\prime} \mathrm{N}$ & $76^{\circ} 57.7^{\prime} \mathrm{N}$ & $77^{\circ} 33.0^{\prime} \mathrm{N}$ \\
$\quad$ Longitude & $18^{\circ} 07.5^{\prime} \mathrm{W}$ & $15^{\circ} 34.5^{\prime} \mathrm{W}$ & $15^{\circ} 03.9^{\prime} \mathrm{W}$ & $15^{\circ} 00.2^{\prime} \mathrm{W}$ & $19^{\circ} 05.0^{\prime} \mathrm{W}$ \\
Water depth $(\mathrm{m})$ & 329 & 155 & 115 & 138 & 175 \\
BW temp $\left({ }^{\circ} \mathrm{C}\right)$ & 7.0 & 2.6 & 0.2 & 2.8 & -1.7 \\
BW oxygen $(\mu \mathrm{M})$ & 289 & 321 & 347 & 326 & 328 \\
$(\%$ sat. $)$ & $(96 \%)$ & $(97 \%)$ & $(97 \%)$ & $(98 \%)$ & $(89 \%)$ \\
BW nitrate $(\mu \mathrm{M})$ & 12 & 11 & 9 & 10 & 12 \\
Fauna $(\mathrm{LOI})\left(\mathrm{g} \mathrm{m} \mathrm{m}^{-2}\right)$ & $\mathrm{nm}$ & 10.6 & 7.7 & 10.4 & 19.7 \\
\hline
\end{tabular}

plastic vials for later analysis of nutrients $\left(\mathrm{NO}_{3}{ }^{-}\right.$and $\left.\mathrm{NH}_{4}{ }^{+}\right)$. For DIC determinations, $7 \mathrm{ml}$ was transferred into gas-tight excetainers (Labco, High Wycombe, UK) and conserved with $\mathrm{HgCl}_{2}$. The remaining sample was filtered and $0.5 \mathrm{M} \mathrm{NaOH}$ was added in a ratio of 1:50 (Broström \& Broström 1991), the precipitate was later analyzed for manganese. The retrieved sediment was sieved through a $1 \mathrm{~mm}$ mesh screen and fauna was preserved in $76 \%$ ethanol.

The profiling lander was equipped with $7 \mathrm{O}_{2}$ microelectrodes, and profiles were obtained at a spatial resolution of 100 um (Gundersen \& Jørgensen 1990,

The chamber of 'Elinor' was implanted approximately $20 \mathrm{~cm}$ into the sediment and it enclosed $896 \mathrm{~cm}^{2}$ of surface area. After $1 \mathrm{~h}$, lid closure initiated incubations, during which an impeller stirred the 8 to $12 \mathrm{~cm}$ high water column. The constant stirring ( $8 \mathrm{rpm})$ ensured a well-mixed water phase and gave rise to a diffusive boundary layer (DBL) thickness for $\mathrm{O}_{2}$ of approximately $520 \mu \mathrm{m}$ over $91 \%$ of the sediment surface area (Glud et al. 1995). Two minielectrodes measured the $\mathrm{O}_{2}$ concentration of the enclosed water, and a water sampling system retrieved 8 to 10 water samples of $60 \mathrm{ml}$ at predefined time intervals. A part of some samples was stored in $11 \mathrm{ml}$ glass ampoules while the rest was stored in $60 \mathrm{ml}$ plastic syringes. The sampled volume was replaced by bottom water, and the $0.7 \%$ dilution was later corrected for. At the end of the incubation a scoop closed beneath the chamber and the incubated sediment was recovered together with the lander.

It has been shown that central stirring of benthic chambers creates radial pressure gradients, which can initiate advective porewater transport in permeable sediments (Huettel \& Gust 1992a, Glud et al. 1996). However, the sediments we investigated were fine grained and highly impermeable. Enhanced flushing of empty burrows caused by the stirring cannot be completely excluded. However, the maximal pressure gradient in the chamber at the applied stirring rate was $0.048 \mathrm{~Pa} \mathrm{~cm}^{-1}$ (Glud et al. 1995), which can only marginally affect flushing of U-shaped burrows (Huettel \& Gust 1992b).

After lander retrieval the water samples were treated in the following way: Winkler reagents were added to the glass ampoules and the $\mathrm{O}_{2}$ concentration was subsequently determined by titration (Strickland \& Parsons 1972). These values were used for calibration of the $\mathrm{O}_{2}$ minielectrodes, together with an on board zero point reading of the sensors at in situ temperature. Ten $\mathrm{ml}$ of sample from the syringes was filtered and frozen in
Glud et al. 1994a). The microelectrodes were Clark type sensors equipped with a guard cathode and an internal reference (Revsbech 1989). The tip diameter of the sensors was 5 to $20 \mu \mathrm{m}$, the stirring effect was $<1 \%$ and the $90 \%$ response time $<1$ s (Revsbech 1989). A bottom-water sample was retrieved together with the lander for sensor calibration. Two calibration points were inherent in the measured profiles, the signal in the bottom water and the constant low reading in the anoxic sediment. A camera (Photosea 1000A) was mounted on 'Profilur' and 30 photographs of the sediment surface were taken during each deployment.

Laboratory measurements. From each station, 8 to 10 sediment cores (inner diameter $9.6 \mathrm{~cm}$; length approx. $30 \mathrm{~cm}$ ) were recovered with a 'multiple corer' (Barnett et al. 1984).

Total exchange and denitrification rates: Six sediment cores were placed in an incubation tank filled with bottom water kept at in situ temperature. The water was flushed with a gas mixture, regulated by a digital gas mixer (Brooks Instruments), in order to keep the concentrations of $\mathrm{O}_{2}, \mathrm{CO}_{2}$ and $\mathrm{pH}$ at in situ values. An external magnet drove the rotation of small tefloncoated magnets, which were attached to the inner wall of each coreliner, this ensured a well-mixed overlying water phase inside the tubes (Rasmussen \& Jørgensen 1992). After pre-incubation (12 to $24 \mathrm{~h}$ ), 3 cores were capped, leaving an internal water height of approximately $10 \mathrm{~cm}$. Cores were incubated for about $800 \mathrm{~min}$, during which 5 subsamples of $60 \mathrm{ml}$ were collected at equally spaced time intervals. The sample volume was replaced with water from the incubation tank, and the approximately $8 \%$ dilution was corrected for. These samples were treated in the same way as the water samples retrieved by 'Elinor'.

For denitrification measurements ${ }^{15} \mathrm{~N}$-labeled nitrate was added to a final concentration of approximately $70 \mu \mathrm{M}$ in the overlying water of the 3 remaining cores, 
which were incubated for approximately 24 h. During this period the $\mathrm{O}_{2}$ concentration did not decrease by more than $25 \%$ of the initial value. At the end of the incubation, a $10 \mathrm{ml}$ water sample was taken for determination of the $\mathrm{NO}_{3}{ }^{-}$and $\mathrm{NH}_{4}{ }^{+}$concentrations. To determine the amount of ${ }^{15} \mathrm{~N}$-enriched $\mathrm{N}_{2}$ that had accumulated in the overlying water during the incubation, water samples of $7 \mathrm{ml}$ were gently transferred with glass syringes to $7 \mathrm{ml}$ gas-tight excetainers containing $200 \mu$ saturated $\mathrm{ZnCl}_{2}$ solution. Subsequently, $1 \mathrm{ml} \mathrm{ZnCl}$ solution was added to the cores and the upper $5 \mathrm{~cm}$ of the sediment was gently mixed into a slurry from which $7 \mathrm{ml}$ were transferred into gas-tight excetainers (Nielsen 1992).

Microelectrode profiles: The 3 cores used for the total exchange measurements were uncapped and allowed to re-equilibrate for $24 \mathrm{~h}$. Subsequently a total of 5 to $11 \mathrm{O}_{2}$ microprofiles were measured in the cores. Sensor characteristics were the same as for the microelectrodes applied in situ. The sensors were positioned by a motor-driven micromanipulator and the sensor current was measured with a picoammeter connected to an A-D converter, which transferred the signals to a PC (Revsbech \& Jørgensen 1986). The profiles were obtained at a spatial resolution of $100 \mu \mathrm{m}$. No significant difference was observed between profiles obtained in different cores from a given station or between profiles measured before and after core incubations (data not shown).

Porewater profiles: WCS was employed to determine porewater concentrations of $\mathrm{O}_{2}, \mathrm{DIC}, \mathrm{NO}_{3}{ }^{-}$and $\mathrm{NH}_{4}{ }^{+}$(Bender et al. 1987). A plexiglass piston fitted with $\mathrm{O}$-rings was placed in the bottom of a core liner, a car jack was used to press the sediment against a filter screen fitted into an O-ring-sealed lid covering the core. The porewater was channeled through gas-tight tubing into sampling containers $(1.8 \mathrm{ml}$ cryovials). The tip of a Clark type $\mathrm{O}_{2}$ electrode was placed in the tubing and continuousily measured the $\mathrm{O}_{2}$ concentration of the porewater removed. By combining data for the volume of porewater collected and porosity, sediment profiles could be constructed. The main advantage of the WCS technique is the high resolution (in our case approx. $0.7 \mathrm{~mm}$ ) compared to core slicing techniques. We note, however, that our porosity data were determined at a somewhat coarser resolution. Two to four profiles were measured at each station. About half of the cores were squeezed directly after recovery, while the rest were taken after sediment incubation and microprofiling.

Chemical analyses. More elaborate and higher precision techniques than those used for porewater concentrations are required for measuring solute concentration changes during core incubation. For that reason different techniques were used for the 2 sets of samples.
Porewater samples: DIC and $\mathrm{NH}_{4}{ }^{+}$concentrations were measured by a flow injection system with gasexchange and conductivity detection of both species (Hall \& Aller 1992). Concentrations of $\mathrm{NO}_{3}{ }^{-}+\mathrm{NO}_{2}{ }^{-}$were determined after reduction with V(III) to NO with subsequent detection by chemiluminescence (Braman \& Hendrix 1989). The standard deviation of duplicate analyses was around $1 \%$. This method offers the specific advantages of rapid analysis time (approx. 2 min) and good sensitivity $(0.1 \mu \mathrm{M})$ with sample sizes of $100 \mu \mathrm{l}$. In many instances $\mathrm{NO}_{3}{ }^{-}+\mathrm{NO}_{2}{ }^{-}$were also determined by shaking samples with spongy cadmium. The $\mathrm{NO}_{3}{ }^{-}$was thereby reduced to $\mathrm{NO}_{2}{ }^{-}$, and the total $\mathrm{NO}_{2}{ }^{-}$ was subsequently determined colorimetrically with a standard deviation of 4 to $5 \%$ (Jones 1984). Comparable results were obtained by these methods, although the precision was much better with chemiluminescence detection.

Incubation samples: The conserved DIC samples from both the in situ and laboratory incubations were determined with a coulometer (VIC, CM 5012) (Johnson et al. 1987) modified to work with a $4 \mathrm{ml}$ sample volume. The frozen nutrient samples were thawed and filtered. The concentrations of $\mathrm{NO}_{3}{ }^{-}+\mathrm{NO}_{2}{ }^{-}$were determined on a flow injection analyzer (Tecator, Höganäs, Sweden) using the method described by Grasshoff et al. (1983), while $\mathrm{NH}_{4}{ }^{+}$concentrations were determined manually using the method of Bower \& Hansen (1980). For manganese, the samples were preconcentrated and measured by flame atomic absorption spectroscopy (Perkin Elmer) as described by Thamdrup et al. (1994). For determination of the isotope ratios ${ }^{28} \mathrm{~N}_{2} /{ }^{29} \mathrm{~N}_{2}$ and ${ }^{28} \mathrm{~N}_{2} /{ }^{30} \mathrm{~N}_{2}$ in the collected $\mathrm{N}_{2}$ gas, the $\mathrm{N}_{2}$ in the excetainers was extracted into a $4 \mathrm{ml}$ He head space by vigorous shaking and injected into a gas chromatograph in line with a triple collector mass spectrometer (Tracemass, Europa Scientific, UK) (Risgaard-Petersen \& Rysgaard 1995).

The collected fauna were categorized and the dry weight of each group was quantified after drying for $24 \mathrm{~h}$ at $90^{\circ} \mathrm{C}$; the loss by ignition at $550^{\circ} \mathrm{C}$ was subsequently determined (Table 1). The organic carbon and total $\mathrm{N}$ were determined in dried sediment on an elemental analyzer (Carlo Erba; SD 2\%); inorganic carbon was removed by acidification $(\mathrm{HCl})$ and drying of the sample boats prior to analysis.

Sediment cores recovered by the multiple corer and those which had no visual traces of bioturbation were selected and sectioned into 1 and $2 \mathrm{~cm}$ slices. After sectioning, the sediment was air-dried and homogenized with a mortar and pestle. The activities of ${ }^{210} \mathrm{~Pb}$ and ${ }^{226} \mathrm{Ra}$ were determined by gamma counting. Unsupported ${ }^{210} \mathrm{~Pb}$ activity was taken as the difference between total ${ }^{210} \mathrm{~Pb}$ activity and the activity of ${ }^{226} \mathrm{Ra}$. 
Calculations. From the porewater profiles a simple 1-dimensional diffusion flux $(J)$ was calculated for $\mathrm{O}_{2}$, DIC. $\mathrm{NH}_{4}{ }^{+}$and $\mathrm{NO}_{3}{ }^{-}$by Fick's first law of diffusion: $J=-D_{\mathrm{s}}(x) \phi(z)(\mathrm{d} C / \mathrm{d} z)$, where $D_{\mathrm{s}}$ is the sediment diffusion coefficient for each solute $(x), \phi$ is the porosity and $C$ is the solute concentration at a given depth ( $z$ ). It was assumed that $D_{\mathrm{s}}=D_{0} \phi^{2}$ (Ullman \& Aller 1982), where $D_{0}$ is the solute diffusion coefficient in water. For the $\mathrm{O}_{2}$ microprofiles we used the concentration gradient in the DBL and therefore the diffusional term $D_{s} \phi(z)$ could be replaced by $D_{0}$ (Revsbech \& Jørgensen 1986). The upper boundary of the DBL was defined as the intersection point between the extrapolated linear $\mathrm{O}_{2}$ gradient in the DBL and the constant $\mathrm{O}_{2}$ value in the overlying water (Revsbech \& Jørgensen 1986). The position of the sediment surface was typically indicated by a distinct break in the measured microprofiles (see Fig. 4). The temperature-corrected $D_{0}$ values for the different solutes were taken from Broecker \& Peng (1974) and Li \& Gregory (1974). The total exchange rates of solutes were calculated by linear regression of solute concentrations as a function of incubation time. Fauna-mediated $\mathrm{O}_{2}$ uptake was estimated by subtracting the diffusive flux (DOU), calculated from microprofiles, from the total $\mathrm{O}_{2}$ uptake (TOU) measured by sediment incubation (e.g. Archer \& Devol 1992, Glud et al. 1994a).

Rates of denitrification based both on $\mathrm{NO}_{3}{ }^{-}$supplied from the overlying water $\left(\mathrm{D}^{\mathrm{w}}{ }_{14}\right)$ and nitrate produced from nitrification within the sediment $\left(D^{n}{ }_{14}\right)$ were calculated by the isotope pairing technique as described by Nielsen (1992). This calculation assumes (1) a uniform mixing of the added ${ }^{15} \mathrm{NO}_{3}{ }^{-}$and the endogenous ${ }^{14} \mathrm{NO}_{3}{ }^{-}$pool, (2) that the addition of ${ }^{15} \mathrm{~N}$-labeled $\mathrm{NO}_{3}{ }^{-}$ does not alter the original denitrification rate and (3) that a steady-state gradient of ${ }^{15} \mathrm{NO}_{3}{ }^{-}$is established in a short time relative to the total incubation time. For a detailed discussion of the technique and the assumptions, refer to Middelburg et al. (1996) and Nielsen et al. (1996)

\section{RESULTS}

\section{Sediment}

All stations had silty and cohesive sediments with few stones ( $<1 \%$ vol.) in the upper $20 \mathrm{~cm}$. The surface porosity varied from 0.77 to 0.83 and gradually decreased to around $10 \mathrm{~cm}$ depth, below which it remained constant (Fig. 2). The same was observed for organic $\mathrm{C}$, which reached values of 1.5 to $2.5 \mathrm{wt} \%$ at the surface (Fig. 2). The organic carbon values were comparable to measurements performed by Hulth et al. (1996) for shelf sediments around Svalbard. Unsup-
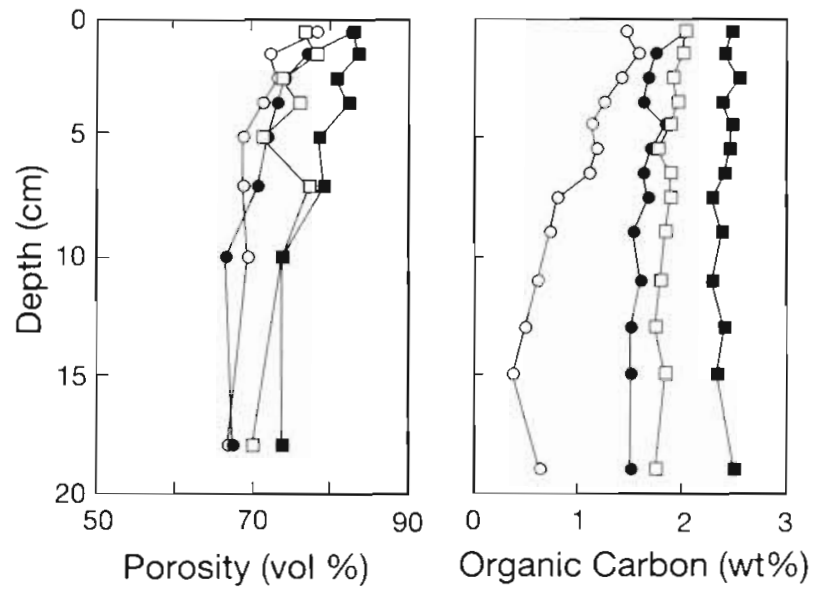

Fig. 2. Profiles of porosity and organic carbon content at

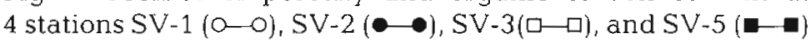

ported ${ }^{210} \mathrm{~Pb}$ content decreased exponentially with depth below a surface zone with evident mixing. Surface mixed layers were particularly prominent at SV-3 and SV-5 (Fig. 3). Sediment accumulation rates based on the exponential decrease in unsupported ${ }^{210} \mathrm{~Pb}$ activity were 1.3 (SV-1), 5.9 (SV-2), 2.5 (SV-3), and $2.1 \mathrm{~mm} \mathrm{yr}^{-1}$ (SV-5). No ${ }^{210} \mathrm{~Pb}$ determinations were made at SV-4, but, as reflected by data below, conditions at SV-3 and SV-4 were similar and we have assumed identical accumulation rates at the 2 stations.

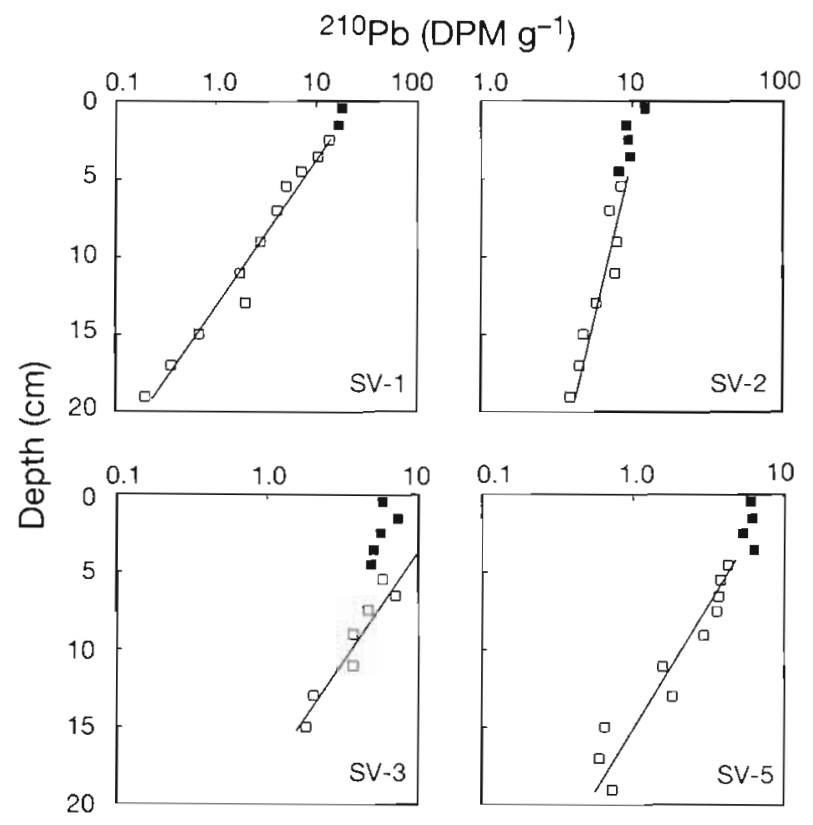

Fig. 3. Profiles of unsupported ${ }^{210} \mathrm{~Pb}$ at 4 stations. The surface zone affected by bioturbation (a) was omitted in the linear regression. The regression lines used for calculating the benthic accumulation rates are indicated $\left(\mathrm{r}^{2}=0.98\right.$ [SV-1], $0.92[\mathrm{SV}-2], 0.90[\mathrm{SV}-3], 0.91[\mathrm{SV}-5])$ 


\section{Oxygen profiles}

For most stations the average $\mathrm{O}_{2}$ penetration depth determined from the in situ microprofiles was around $10 \mathrm{~mm}$, only SV-2 had a significantly smaller $\mathrm{O}_{2}$ penetration of approximately $5 \mathrm{~mm}$ (Table 2). A high biological activity at this station was also reflected by the average diffusive $\mathrm{O}_{2}$ uptake (DOU) of $9.1 \mathrm{mmol}$ $\mathrm{m}^{-2} \mathrm{~d}^{-1}$ compared to $4.5-7.4 \mathrm{mmol} \mathrm{m} \mathrm{m}^{-2} \mathrm{~d}^{-1}$ at the 4 other stations (Table 2). The $\mathrm{O}_{2}$ profiles obtained at each individual station were, however, very different. Some profiles had local $\mathrm{O}_{2}$ maxima, while others showed local temporally fluctuating signals, presumably caused by bioirrigation (Fig. 4A). In total, 41 microprofiles were obtained in situ and $35 \%$ were visibly affected by faunal activity. Even profiles without any visible anomaly had pronounced differences in shape, penetration depth, DOU and DBL thickness (Table 2, Fig. 4A). Except for SV-2, all in situ profiles were obtained at a single lander deployment and within a sediment area of $133 \mathrm{~cm}^{2}$. The variation among profiles within such a small area suggested a highly heterogeneous sediment. This was confirmed by photographs, obtained in situ, in which the sediment surface displayed extensive microtopography, high densities of active fauna and biogenic structures (Fig. 5). For the values computed in Table 2, profiles affected by irrigation were excluded. The $\mathrm{O}_{2}$ microprofiles measured in the recovered cores were generally similar to those obtained in situ (Fig. 4, Table 2). The DBL thickness resulting from laboratory stirring was thicker than that found in situ, but no significant difference in $\mathrm{O}_{2}$ penetration or DOU could be observed between labora-
Table 2. Diffusive $\mathrm{O}_{2}$ uptake (DOU), $\mathrm{O}_{2}$ penetration depth (OP) and DBL thickness determined from microprofiles obtained in the laboratory and in situ, and DOU and OP determined from WCS profiles. Standard deviations are indicated. Number of profiles used for the calculation shown in parentheses. nm: not measured

\begin{tabular}{|c|c|c|c|}
\hline & $\begin{array}{c}\mathrm{O}_{2} \text { profiles } \\
\text { in situ }\end{array}$ & $\begin{array}{c}\mathrm{O}_{2} \text { profiles } \\
\text { in laboratory }\end{array}$ & $\begin{array}{l}\mathrm{O}_{2} \text { profiles } \\
\text { from WCS }\end{array}$ \\
\hline \multicolumn{4}{|l|}{ SV-1 } \\
\hline DOU (mmol m $\left.\mathrm{m}^{-2} \mathrm{~d}^{-1}\right)$ & $-7.4 \pm 1.2(4)$ & $-6.7 \pm 0.9(8)$ & $-4.1 \pm 0.1(2)$ \\
\hline $\mathrm{OP}(\mathrm{mm})$ & $9.9 \pm 0.6(5)$ & $8.9 \pm 1.0(7)$ & $15.9 \pm 0.0(2)$ \\
\hline DBL thickness $(\mu \mathrm{m})$ & $703 \pm 143\{5\}$ & $1063 \pm 271(7)$ & \\
\hline \multicolumn{4}{|l|}{ SV-2 } \\
\hline $\mathrm{DOU}\left(\mathrm{mmol} \mathrm{m} \mathrm{m}^{2} \mathrm{~d}^{-1}\right)$ & $-9.1 \pm 5.4(9)$ & $-9.6 \pm 2.5(5)$ & $-3.2 \pm 0.7(3)$ \\
\hline$O P(\mathrm{~mm})$ & $5.5 \pm 2.2(12)$ & $3.6 \pm 0.4(5)$ & $10.9 \pm 2.4(3)$ \\
\hline DBL thickness $(\mu \mathrm{m})$ & $489 \pm 120(9)$ & $946 \pm 158(5)$ & \\
\hline \multicolumn{4}{|l|}{ SV-3 } \\
\hline DOU (mmol m-2 $\left.\mathrm{d}^{-1}\right)$ & $-4.5 \pm 3.9(5)$ & $-4.2 \pm 0.9(5)$ & $-1.4 \pm 0.5(3)$ \\
\hline $\mathrm{OP}(\mathrm{mm})$ & $9.6 \pm 2.6(5)$ & $8.2 \pm 0.9(5)$ & $13.7 \pm 3.8(3)$ \\
\hline DBL thickness $(\mu \mathrm{m})$ & $779 \pm 211(5)$ & $1446 \pm 207(5)$ & \\
\hline \multicolumn{4}{|l|}{ SV-4 } \\
\hline $\operatorname{DOU}\left(\mathrm{mmol} \mathrm{m} \mathrm{m}^{-2} \mathrm{~d}^{-1}\right)$ & $-6.1 \pm 3.0(4)$ & $-5.0 \pm 0.9(6)$ & $\mathrm{nm}$ \\
\hline $\mathrm{OP}(\mathrm{mm})$ & $9.3 \pm 3.4(4)$ & $8.3 \pm 0.7(7)$ & $\mathrm{nm}$ \\
\hline DBL thickness $(\mu \mathrm{m})$ & $611 \pm 135(5)$ & $1008 \pm 177(7)$ & \\
\hline \multicolumn{4}{|l|}{ SV-5 } \\
\hline DOU (mmol m $\left.\mathrm{m}^{-2} \mathrm{~d}^{-1}\right)$ & $-5.1 \pm 1.2(5)$ & $-4.3 \pm 2.2(9)$ & $-2.9 \pm 0.4(2)$ \\
\hline $\mathrm{OP}(\mathrm{mm})$ & $10.9 \pm 2.5(7)$ & $8.8 \pm 0.2(11)$ & $17.8 \pm 3.0(2)$ \\
\hline DBL thickness $(\mu \mathrm{m})$ & $795 \pm 181(7)$ & $1021 \pm 224(8)$ & \\
\hline
\end{tabular}
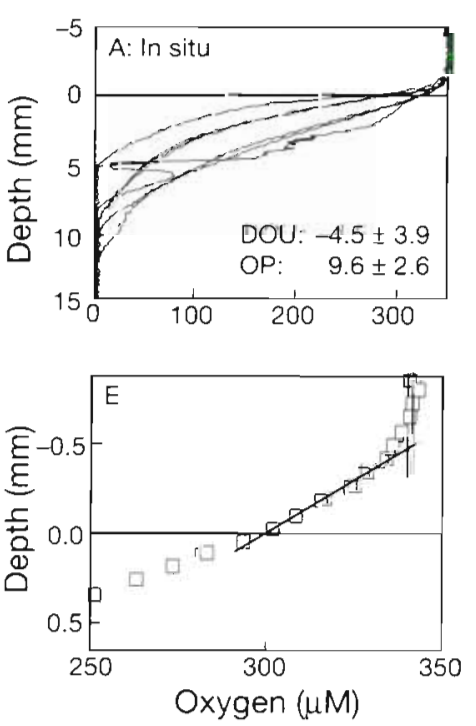

tory and in situ microprofiles (Table 2). Laboratory profiles were, however, more similar to one another compared to the in situ profiles, indicating reduced faunal activity (Table 2, Fig. 4). The $\mathrm{O}_{2}$ profiles measured by the WCS technique had significantly deeper $\mathrm{O}_{2}$ penetration depths compared to the microprofiles (Fig. 4C, Table 2). Furthermore, calculation of DOU from the steepest gradient, immediately below the interface, only resulted in values that accounted for 35 to $55 \%$ of the DOU calculated from the microprofiles (Fig. 4, Table 2)

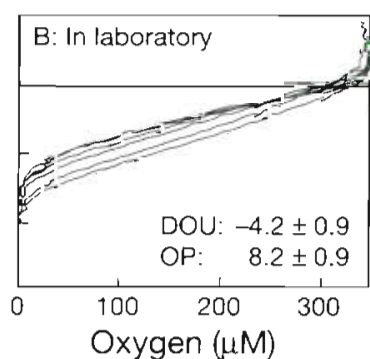

Fig. 4. Oxygen profiles obtained at SV-3 (A) by microelectrodes in situ, (B) in the laboratory, and (C) by the WCS technique. (D, E) Single profile taken from (A) illustrating the spatial resolution of the obtained profiles (D) and the concentration gradient through the DBL used for calculating the diffusive $\mathrm{O}_{2}$ uptake (DOU) (E). In (C): $(\mathbf{\square}, \bullet)$ profiles obtained in cores used for incubations prior to $\operatorname{WCS}_{i}(\square, \diamond)$ profiles obtained immediately after core recovery. The units for DOU are $\mathrm{mmol} \mathrm{m} \mathrm{m}^{-2} \mathrm{~d}^{-1}$ and for $\mathrm{O}_{2}$ penetration (OP) units are mm. Standard deviation for each parameter is included. Note the different axes scales 


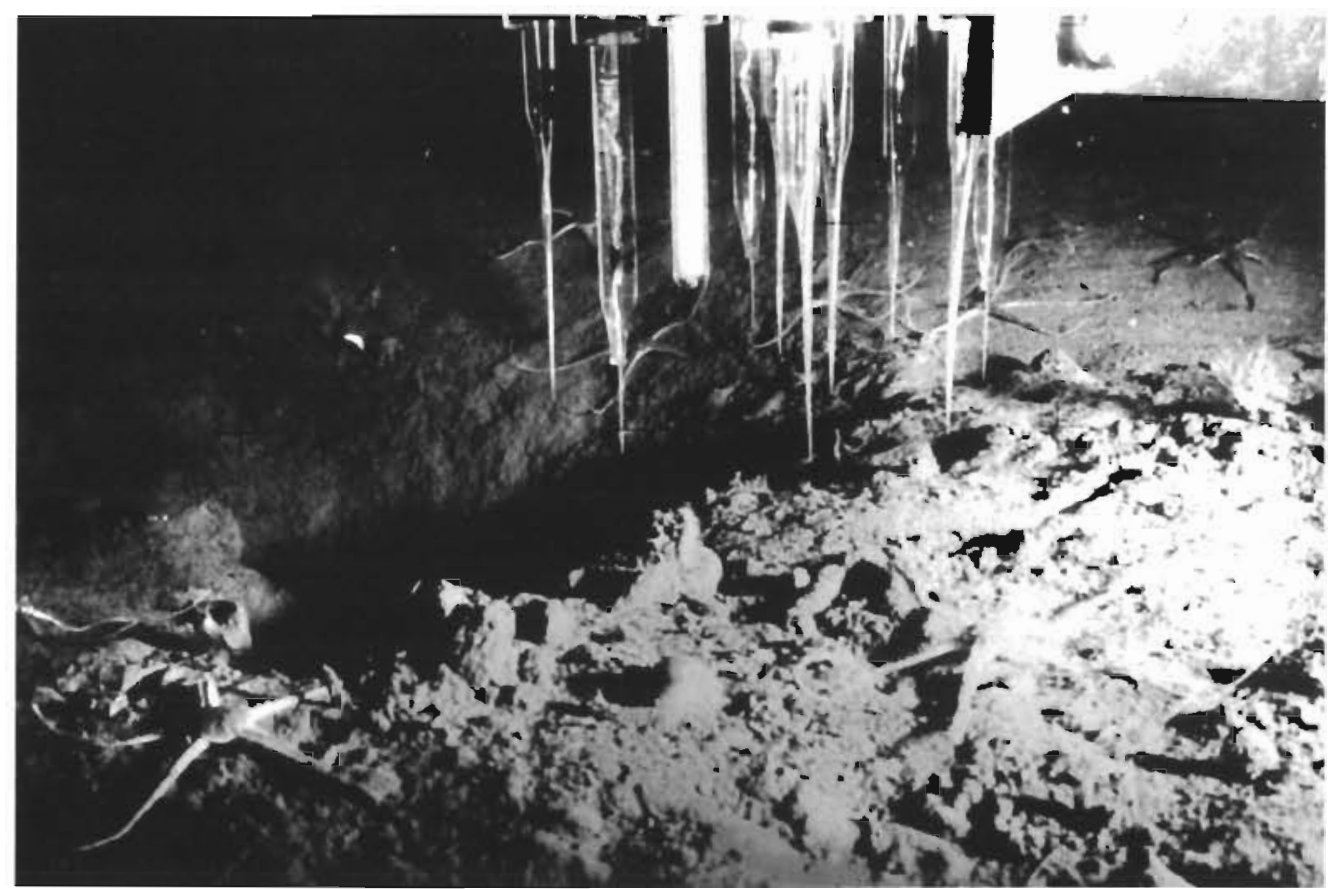

Fig. 5. Photograph of the sediment surface at SV-5. The tips of the microsensors from 'Profilur' can be seen in the center, while different species of macrofauna can be observed at the sediment surface. The burrow behind the sensors was the nest of a lobster that occasionally could be seen on some of the obtained photographs

\section{Porewater profiles of DIC, $\mathrm{NH}_{4}^{+}$and $\mathrm{NO}_{3}{ }^{-}$}

The porewater profiles of $\mathrm{DIC}, \mathrm{NH}_{4}^{+}$and $\mathrm{NO}_{3}{ }^{-}$ showed the same qualitative trends at all stations. As an example of the WCS results, all profiles obtained at SV-2 and SV-3 are presented in Fig. 6. Generally, DIC increased linearly from the sediment surface to the depth of sampling. Using the gradient immediately below the interface, the efflux of DIC was calculated to be between 1.5 and $3.1 \mathrm{mmol} \mathrm{m}^{-2} \mathrm{~d}^{-1}$, high-
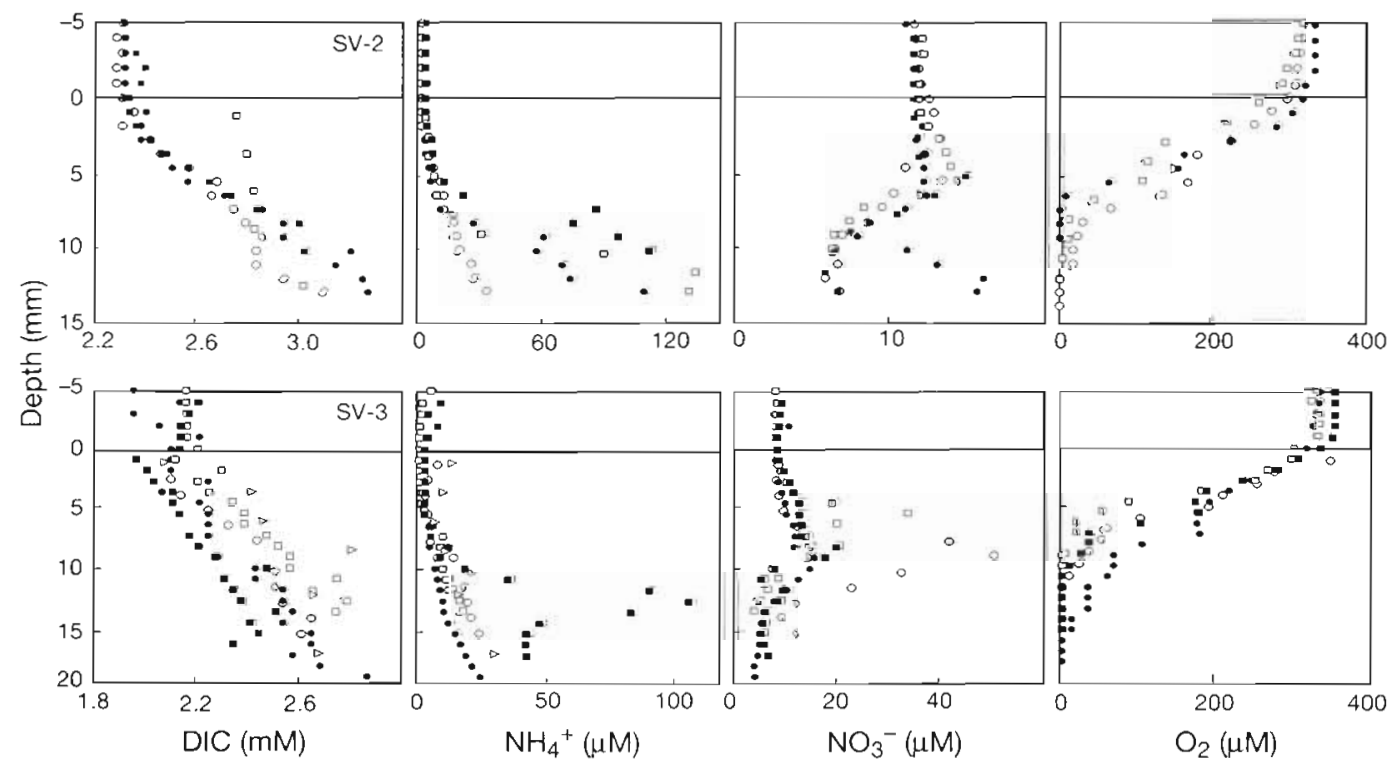

Fig. 6. Porewater profiles of $\mathrm{DIC}, \mathrm{NH}_{4}{ }^{+}, \mathrm{NO}_{3}{ }^{-}$and $\mathrm{O}_{2}$ as obtained by WCS from SV-2 and SV-3. Horizontal lines indicate sediment surface. $(\square, O, \triangleright)$ Profiles obtained immediately after core retrieval; (

$(\bullet, \bullet)$ profiles obtained after initial core incubation and microprofiling 
Table 3. Diffusive tluxes as calculated from the pore water gradients obtained by WCS. The oxic zone is defined by the OP from WCS (Table 2). Standard deviations are indicated. Number of profiles used for the calculation shown in parentheses. nm: not measured

\begin{tabular}{|c|c|c|c|c|c|}
\hline Porewater flux (mmol $\mathrm{m}^{-2} \mathrm{~d}^{-1}$ ) & SV-1 & $\mathrm{SV}-2$ & SV-3 & $\mathrm{SV}-4$ & SV-5 \\
\hline DIC from the sediment & $2.3 \pm 0.5(2)$ & $3.1 \pm 0.5(3)$ & $1.5 \pm 0.4(4)$ & $\mathrm{nm}$ & $1.7 \pm 0.2(3)$ \\
\hline $\mathrm{NH}_{4}{ }^{+}$from the sediment ${ }^{d}$ & $0 \pm 0(3)$ & $0 \pm 0(4)$ & $0 \pm 0(3)$ & $\mathrm{nm}$ & $0 \pm 0(3)$ \\
\hline $\mathrm{NH}_{4}^{+}$into oxic zone $e^{b}$ & $0.07 \pm 0.03$ & $0.54 \pm 0.32(2)$ & $0.14 \pm 0.01$ & $\mathrm{~nm}$ & $0.07 \pm 0.03(3)$ \\
\hline $\mathrm{NO}_{3}{ }^{-}$from the sediment ${ }^{d}$ & $0.06 \pm 0.00(2)$ & $0.03 \pm 0.03(4)$ & $0.04 \pm 0.02(3)$ & $\mathrm{nm}$ & $0.03 \pm 0.02(2)$ \\
\hline $\mathrm{NO}_{3}^{-}$to anoxic zone $\mathrm{b}^{\mathrm{b}}$ & $0.12 \pm 0.01(2)$ & $0.16 \pm 0.04(4)$ & $0.18 \pm 0.04(3)$ & $n m$ & $0.07 \pm 0.02(2)$ \\
\hline
\end{tabular}

est at SV-2 and lowest at SV-3 and SV-5 (Table 3). No $\mathrm{NH}_{4}{ }^{+}$efflux was indicated by the porewater profiles, which would be consistent with a $100 \%$ nitrification or assimilation of $\mathrm{NH}_{4}{ }^{+}$within the oxic zone (Fig. 6). The $\mathrm{NO}_{3}^{-}$profiles generally exhibited a peak that overlapped with the depth where $\mathrm{NH}_{4}{ }^{+}$was consumed. This indicates that $\mathrm{NH}_{4}{ }^{+}$diffusing up from the deeper parts of the sediment was nitrified in the oxic zone and the $\mathrm{NO}_{3}{ }^{-}$subsequently diffused away from this horizon. Apparently the nitrification zone overlapped with the oxic layer (Figs. 6 \& 7). The $\mathrm{NO}_{3}{ }^{-}$efflux from the sediment as calculated from the profiles was low and in the range 0.03 to $0.06 \mathrm{mmol}$ $\mathrm{m}^{-2} \mathrm{~d}^{-1}$ (Table 3). The rate of denitrification coupled to nitrification was estimated from the WCS cores and calculated as the difference between $\mathrm{NH}_{4}{ }^{+}$diffusing into the oxic zone and the net efflux of $\mathrm{NO}_{3}^{-}$from the sediment. Values varied between 0.01 and $0.50 \mathrm{mmol} \mathrm{N} \mathrm{m}^{-2} \mathrm{~d}^{-1}$, being highest at $\mathrm{SV}-2$ (Table 3 ). The solute distributions obtained by WCS immediately after core recovery were no different than the porewater distributions determined after core

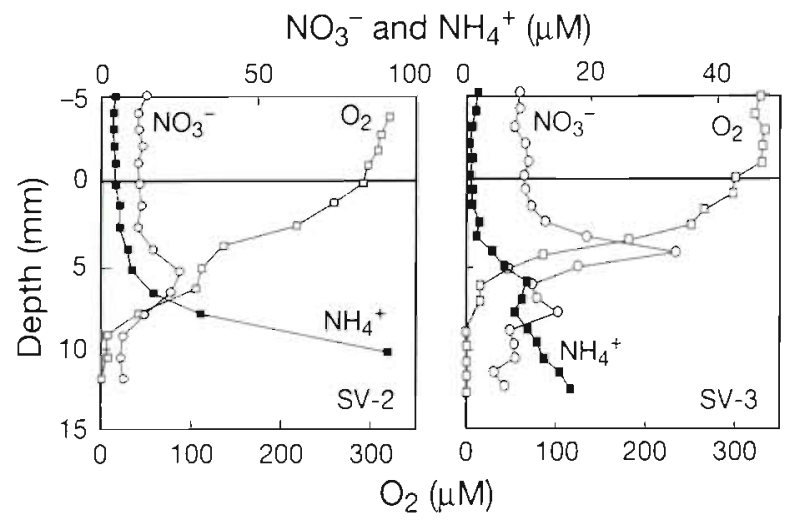

Fig. 7 Solute profiles obtained in a single core by WCS at SV-2 and SV-3. Horizontal lines indicate sediment surface. Depth scale for SV-3 has been reduced and data points below $13 \mathrm{~cm}$ have been omitted in order to focus on the zone of nitrification incubations (Fig. 6). Single WCS profiles showed occasional scatter, presumably caused by presence of fauna or biogenic structures. Highly anomalous profiles were excluded from the data presented in Table 3

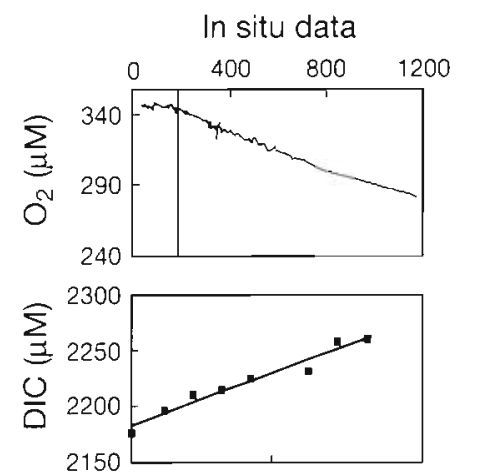

\section{Laboratory}
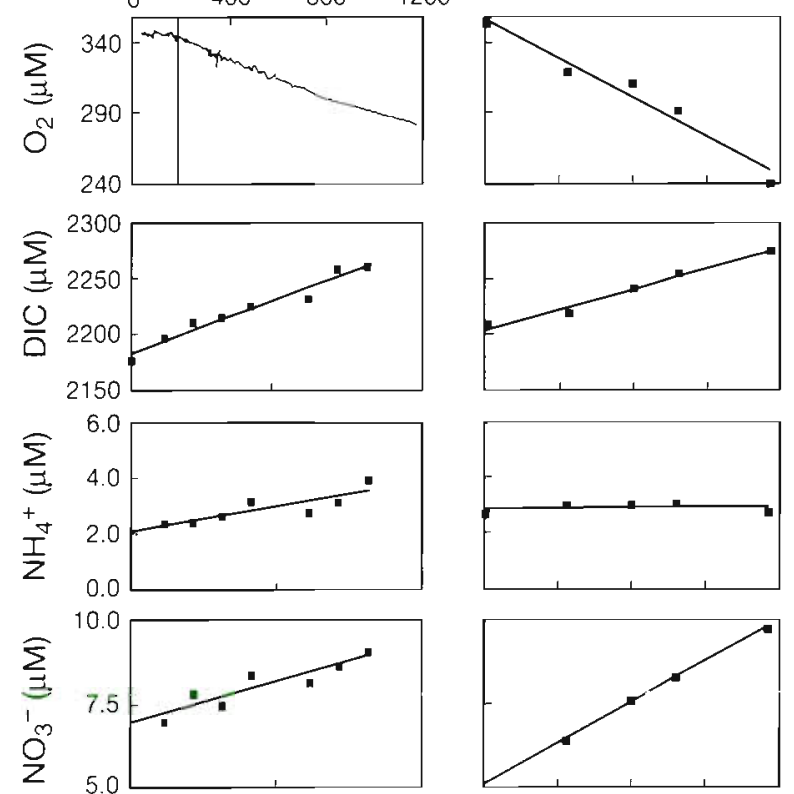

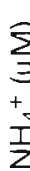
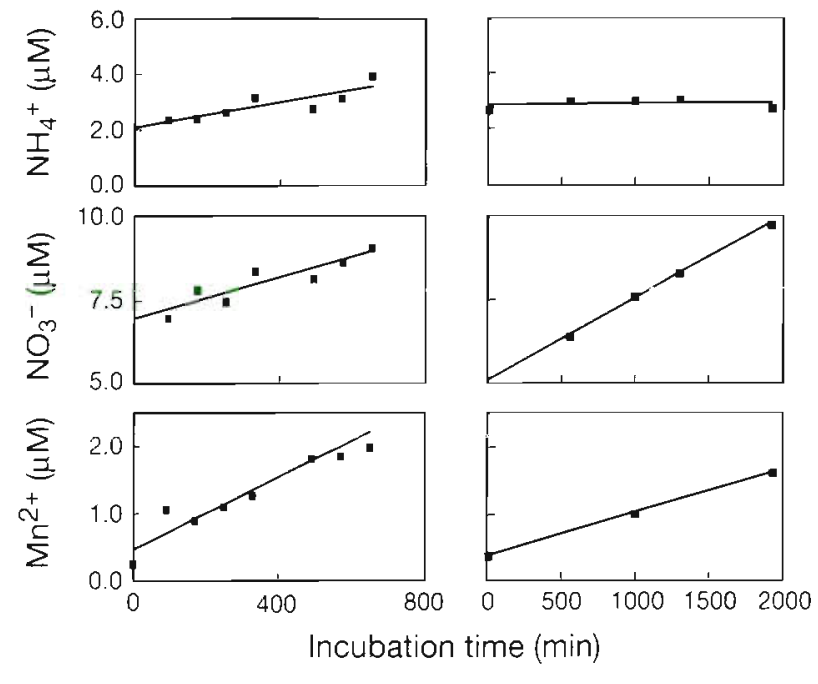

Fig. 8. Solute concentrations as a function of time in the enclosed water of the 'Elinor' chamber and in a laboratoryincubated core from SV-2. The time scale on the panel containing in situ $\mathrm{O}_{2}$ concentrations is different from the rest in order to show the continuous measurements in the bottom water before lid closure (vertical line). Water-column height during the incubations was 7.6 and $10.1 \mathrm{~cm}$ in the laboratory and in situ, respectively 


\section{Total exchange rates}

Linear or near-linear concentration changes in the overlying water were observed in all core incubations (Fig. 8). The solute exchange rates calculated from the in situ flux data were, however, consistently higher than the corresponding rates determined from the laboratory data. For instance, the in situ efflux of DIC varied between 8.8 and $19.8 \mathrm{mmol} \mathrm{m}^{-2} \mathrm{~d}^{-1}$, while the laboratory rates were between 3.7 and $7.8 \mathrm{mmol} \mathrm{m} \mathrm{m}^{-2}$ $\mathrm{d}^{-1}$ (Table 4). The laboratory rates were, however, still approximately 2 to 3 times higher than the rates calculated from the WCS profiles (Tables 3 \& 4). Consistent with the WCS profiles, however, profiles for the laboratory-incubated cores showed no net flux of $\mathrm{NH}_{4}{ }^{+}$. By contrast, there was a significant efflux of $\mathrm{NH}_{4}{ }^{+}$for sediment incubated in situ. The same observation was made for the $\mathrm{Mn}^{2+}$ exchange rates. The nitrate efflux measured in the laboratory was also significantly lower than measured in situ but still much higher than calculated from the WCS profiles. Both laboratory and in situ exchange rates indicated that SV-2 and SV-5 were the stations with highest and lowest activity, respectively.

The fraction of the total $\mathrm{O}_{2}$ uptake (TOU) that was accounted for by molecular diffusion in the in situ incubations varied between 43 and $66 \%$. However, the laboratory incubations showed no significant difference between TOU and DOU (Tables 2 \& 4), indicating that fauna-mediated $\mathrm{O}_{2}$ consumption was of minor importance in the recovered sediment cores as compared to in situ incubations. The amount of fauna present in the Elinor chamber during the incubations, measured as loss on ignition, varied from 7.7 to $19.7 \mathrm{~g}$ $\mathrm{m}^{-2}$ (Table 1). The composition of the larger infauna varied among stations but was always dominated both in weight and numbers by bioirrigating mussels (be-

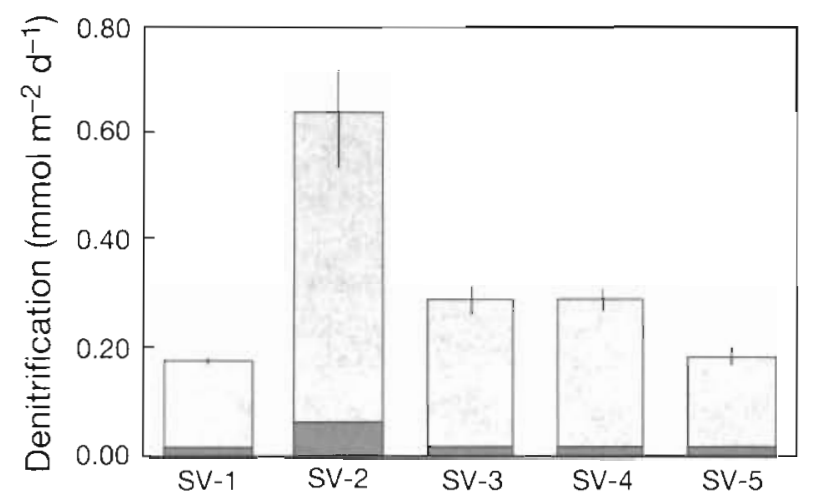

Fig. 9. Denitrification rates at the 5 stations investigated. Light shading: denitrification based on nitrification; dark shading: denitrification based on nitrate from the overlying water Standard deviation of the denitrification rates for the 3 cores investigated is indicated.

tween 140 and 360 ind. $\mathrm{m}^{-2}$ ) and polychaetes (500 to 1050 ind. $\mathrm{m}^{-2}$ ).

The denitrification rates measured in the laboratory by the isotope pairing technique varied from around $0.16 \pm 0.01 \mathrm{mmol} \mathrm{m} \mathrm{m}^{-2} \mathrm{~d}^{-1}$ at SV-1 and SV-5 to $0.63 \pm$ $0.09 \mathrm{mmol} \mathrm{m}^{-2} \mathrm{~d}^{-1}$ at SV-2 (Fig. 9). The rates were consistent with the calculations based on the WCS profiles and also indicate that denitrification was mainly coupled to nitrification. Only at SV-2 did the denitrification based on nitrate from the overlying water exceed $5 \%$ of the total denitrification (Fig. 9).

\section{DISCUSSION}

The main focus of this paper is to quantify and discuss benthic mineralization in the permanently cold sediments of Svalbard; however, the data also offer the

Table 4. Total solute exchange measured in situ and in the laboratory. Standard deviations are indicated. Number of incubations used for the calculations shown in parentheses. In situ incubations at SV-2, SV-3 and SV-4 were performed only once. nm: not measured

\begin{tabular}{|c|c|c|c|c|c|}
\hline & SV -1 & SV-2 & $S V-3$ & $\mathrm{SV}-4$ & SV -5 \\
\hline \multicolumn{6}{|c|}{ In situ flux (mmol $\left.\mathrm{m}^{-2} \mathrm{~d}^{-1}\right)$} \\
\hline $\mathrm{O}_{2}$ & $\mathrm{~nm}$ & -16.4 & -13.1 & -12.2 & $-9.0 \pm 0.9(2)$ \\
\hline DIC & $\mathrm{nm}$ & 19.8 & 17.3 & $\mathrm{~nm}$ & $8.8 \pm 0.1(2)$ \\
\hline $\mathrm{NH}_{4}^{+}$ & $\mathrm{nm}$ & 0.59 & 0.31 & $\mathrm{~nm}$ & $0.11 \pm 0.01(2)$ \\
\hline $\mathrm{NO}_{3}^{-}$ & $\mathrm{nm}$ & 0.69 & 0.44 & $\mathrm{~nm}$ & $0.88 \pm 0.34(2)$ \\
\hline $\mathrm{Mn}^{2+}$ & $\mathrm{nm}$ & 0.28 & 0.33 & $\mathrm{~nm}$ & $0.03 \pm 0.03(2)$ \\
\hline \multicolumn{6}{|c|}{ Laboratory flux (mmol m $\mathrm{m}^{-2} \mathrm{~d}^{-1}$ ) } \\
\hline $\mathrm{O}_{2}$ & $-4.7 \pm 2.5(3)$ & $-8.1 \pm 1.4(2)$ & $-4.2 \pm 1.0(3)$ & $-4.7 \pm 1.5(3)$ & $-3.6 \pm 0.2(3)$ \\
\hline DIC & $5.7 \pm 0.8(3)$ & $7.8 \pm 0.2(2)$ & $-4.4 \pm 1.2(3)$ & $5.1 \pm 0.8(3)$ & $3.7 \pm 1.2(3)$ \\
\hline $\mathrm{NH}_{4}^{+}$ & $0.00 \pm 0.00(6)$ & $0.01 \pm 0.17(7)$ & $0.02 \pm 0.05(6)$ & $0.01 \pm 0.06(6)$ & $0.00 \pm 0.01(6)$ \\
\hline $\mathrm{NO}_{3}^{-}$ & $0.17 \pm 0.04$ & $0.28 \pm 0.10(2)$ & $0.22 \pm 0.09(3)$ & $0.15 \pm 0.04$ & $0.14 \pm 0.01(3)$ \\
\hline $\mathrm{Mn}^{2+}$ & $0.08 \pm 0.04(3)$ & $0.19 \pm 0.06(2)$ & $0.08 \pm 0.06(3)$ & $0.02 \pm 0.01(3)$ & $0.02 \pm 0.01(2)$ \\
\hline
\end{tabular}


opportunity to compare different commonly used techniques for quantifying mineralization.

\section{In situ and laboratory incubations}

In this study we have generated a set of in situ and laboratory flux data for the biologically active solutes of $\mathrm{O}_{2}, \mathrm{DIC}, \mathrm{NH}_{4}^{+}, \mathrm{NO}_{3}^{-}$and $\mathrm{Mn}^{2+}$. In accordance with some previous observations we found significant differences between the 2 incubation techniques (e.g. Devol \& Christensen 1993). In general, the fluxes obtained in the laboratory were markedly lower than the corresponding rates measured in situ. We ascribe the observed differences to exclusion of fauna during laboratory incubations. The cores taken using the multiple corer only enclosed $8 \%$ of the sediment area covered by the benthic chamber, and the edge/area ratio was $0.41 \mathrm{~cm}^{-t}$ as compared to a ratio of $0.13 \mathrm{~cm}^{-1}$ for the benthic chamber. In sediments containing macrofauna, the wall of a small chamber will therefore more often physically affect fauna. Excluding cores with visibly disturbed sediment, typically caused by core liners penetrating burrows or animals, will result in underestimated macrofaunal densities. In this study we used the incubated cores for WCS profiles or denitrification measurements and consequently the faunal density of the cores could not be determined. However, visual inspection of the sediment surface clearly indicated lower faunal densities compared to the sediment surface recovered by the lander chamber.

Different approaches, which to varying degrees account for bioirrigation, bioturbation and fauna metabolism, have previously been applied in order to quantify the fauna-mediated $\mathrm{O}_{2}$ uptake in Arctic sediments. Piepenburg et al. (1995) estimated that, on average, $41 \%$ of the $\mathrm{O}_{2}$ uptake in Barents Sea shelf sediments could be ascribed to the metabolism of macro- and megafauna. In the Bering Sea, Grebmeier \& McRoy (1989) and Blackburn (1987) estimated that macrofauna accounted for 60 to $70 \%$ of the total sediment respiration, while the range in the Chukchi Sea was 5 to $50 \%$ (Blackburn 1987). Previous investigations have revealed that Arctic sediments are rich in fauna (Grebmeier \& McRoy 1989, Høpner-Petersen 1989), and one of the highest biomass densities ever recorded was found in the Barents Sea (Zenkevitch 1963). Our in situ measurements indicate that benthic fauna increased the $\mathrm{O}_{2}$ uptake by a factor of 1.8 to 2.9 over the diffusion-mediated uptake. The in situ microprofiles also demonstrated that irrigating fauna created a complex 3-dimensional $\mathrm{O}_{2}$ distribution of the surface sediments. This is in contrast to Cai \& Sayles (1996), who, based on a compilation of investigations, argued that bioirrigation had a minimal effect on $\mathrm{O}_{2}$ distributions and exchange in coastal sediments. We also note that the in situ efflux of reduced solutes stimulated by irrigation was significantly higher than the comparable rates measured in the laboratory.

The average $\mathrm{O}_{2}$ penetration and. DOU calculated from microprofiles measured in the laboratory were not significantly different from the corresponding values calculated from in situ microprofiles (excluding visually disturbed profiles). Previous investigations have shown that $\mathrm{O}_{2}$ microprofiles in the laboratory reveal lower $\mathrm{O}_{2}$ penetration depths and higher DOU than the in situ profiles as a result of transient heating and decompression during core recovery (Glud et al. 1994a). Due to the shallow water depths and small differences between water and air temperature, such effects were not observed in this study. The DBL impedance against DOU was low $(<6 \%)$ and the thicker DBL applied in the laboratory therefore only affected the benthic $\mathrm{O}_{2}$ distribution marginally (Archer et al. 1989, Glud et al. 1994b). The small variation among microprofiles obtained in the laboratory is probably a combined result of exclusion of fauna, and an unintended biased selection of undisturbed spots for microprofiling.

\section{Whole core squeeze profiles}

Data on the distributions of $\mathrm{O}_{2}, \mathrm{DIC}, \mathrm{NH}_{4}{ }^{+}$and $\mathrm{NO}_{3}{ }^{-}$ from WCS should, in principle, add to our understanding of the rates and dynamics of nitrogen cycling and carbon mineralization in these sediments. As outlined above, the sediment cores incubated in the laboratory exhibited no differences between TOU and DOU, indicating that bioirrigation in these cores was of minor importance. Therefore it was expected that the measured exchange rates of $\mathrm{O}_{2}, \mathrm{DIC}, \mathrm{NH}_{4}{ }^{+}$and $\mathrm{NO}_{3}{ }^{-}$ should correspond to the simple 1-dimensional flux calculations at the interface of WCS profiles.

However, the $\mathrm{O}_{2}$ profiles obtained by WCS exhibited significantly deeper $\mathrm{O}_{2}$ penetration and lower DOU than rates obtained from microprofiles or direct flux measurements in the lab-incubated cores (Tables 2 $\& 4)$. For these calculations, we applied the average porosity determined for the upper $\mathrm{cm}$ of the sediment core $(0.77$ to 0.83$)$, which may underestimate the surface porosity; however, applying a porosity of 0.9 did not change this general observation. Also, fluxes of DIC and $\mathrm{NO}_{3}{ }^{-}$calculated from WCS profiles were consistently lower than the fluxes obtained in the laboratory incubations (Tables 3 \& 4). A correspondence might have been expected between the WCS profiles, microprofiles and fluxes since, in many cases, the same cores used for the lab flux measurements and microprofiling were also squeezed by the WCS technique. In 
contrast to the original report of the WCS technique by Bender et al. (1987), we found an extended smearing of the WSC profiles and suggest that complications arise when applying the WCS technique to fauna-rich heterogeneous sediments.

Nevertheless, the WCS profiles of $\mathrm{NH}_{4}^{+}$were consistent with the lab-obtained flux data; both data sets indicate that regenerated ammonia was completely nitrified in the sediment, and that denitrification was closely coupled to nitrification at the oxic-anoxic interface in the sediment. This was also consistent with the denitrification measurements performed in the laboratory and suggests that the general principles for nitrogen cycling in the recovered cores were mimicked by the WCS technique. It cannot, however, be excluded that absorption of $\mathrm{NH}_{4}{ }^{+}$to oxidized sediment particles affected the $\mathrm{NH}_{4}{ }^{+}$profiles obtained by WCS. We found that denitrification was generally restricted to the lowest part of the oxic zone or immediately below. In fact, any overlap that we observed between $\mathrm{O}_{2}$ and the denitrifying zone may have been a result of profile smearing. These results are in contrast to those of Brandes \& Devol (1995), who found considerable overlap between the oxic and the denitrifying zone in shallow Arctic sediments (Chukchi Sea) and as an explanation proposed the existence of anaerobic microniches with intense denitrification. We found no anoxic microniches in the sediments of Svalbard despite measuring more than $180 \mathrm{O}_{2}$ microprofiles conly data from 64 microprofiles are presented in this study [Table 2, Fig. 4], the rest will be presented elsewhere). An explanation for the difference between our findings and the report of Brandes \& Devol (1995) requires further investigation.

\section{Benthic carbon and nitrogen mineralization in the fjords of Svalbard}

As discussed above we consider in situ benthic exchange rates of DIC and $\mathrm{O}_{2}$ to be the most reliable estimate of total benthic mineralization in the investigated sediments. Benthic mineralization rates and the sediment accumulation rates were correlated, with SV-2 and SV-3 experiencing the highest rates of both carbon mineralization and sediment accumulation (Table 5). In general, our measured $\mathrm{O}_{2}$ and DIC exchange rates are comparable to values previously published for Arctic shelf sediments, but also to rates for lower latitude shelf sediments at significantly higher temperatures (Table 6). Our denitrification rate is comparable to $\mathrm{NO}_{3}{ }^{-}$reduction rates measured at the same station by a sediment slurry technique (Thamdrup \& Fleischer 1998), and shows that denitrification could have only contributed 3 to $4 \%$ of the in situ DIC efflux $x_{i}$ this is comparable to other shelf sediments (e.g. Canfield et al. 1993). If the denitrification rate is low compared to total mineralization, the degradation of organic carbon including both aerobic and anaerobic pathways should, assuming reoxidation of all reduced solutes, roughly give rise to $1 \mathrm{~mol}$ of $\mathrm{CO}_{2}$ for each mol of $\mathrm{O}_{2}$ that is consumed (Canfield et al. 1993). This relation was observed in practically all of our laboratory incubations; however, in situ incubations at SV-2 and SV-3 revealed an increased release rate of DIC compared to the $\mathrm{O}_{2}$ uptake. This imbalance was partly compensated for by relatively high release rates of the reduced solutes $\mathrm{NH}_{4}{ }^{+}$and $\mathrm{Mn}^{2+}$, probably stimulated by irrigation. Our estimated total carbon mineralization rates were not corrected for any $\mathrm{CaCO}_{3}$ dissolution, which, however, must have been of minor importance for the DIC exchange in these active sediments. Nor have we accounted for the exchange of dissolved organic carbon (DOC); however, a study in the same area demonstrated a positive correlation between porewater concentrations of DOC and water depth (Hulth et al. 1996). This observation indicated that in shallow reactive sediments DOC was easily metabolized into DIC and that the efflux of DOC was of minor importance for the benthic carbon release in such sediments (Hulth et al. 1996).

Table 5. Carbon preservation in Svalbard sediments

\begin{tabular}{|c|c|c|c|c|c|c|}
\hline Stn & $\begin{array}{l}\text { Porosity }{ }^{a} \\
(\%)\end{array}$ & $\begin{array}{c}\text { Organic } C^{d} \\
(\%)\end{array}$ & $\begin{array}{l}\text { Sediment accumulation } \\
\qquad\left(\mathrm{g} \mathrm{m}^{-2} \mathrm{~d}^{-1}\right)\end{array}$ & $\begin{array}{l}\text { Benthic C mineralization } \\
\qquad\left(\mathrm{mmol} \mathrm{m} \mathrm{m}^{-2} \mathrm{~d}^{-1}\right)\end{array}$ & $\begin{array}{c}\text { C burial } \\
\left(\mathrm{mmol} \mathrm{m} \mathrm{m}^{-2} \mathrm{~d}^{-1}\right)\end{array}$ & $\begin{array}{l}\text { C preservation } \\
(\% \text { of settling } C)\end{array}$ \\
\hline SV-1 & 0.68 & 0.6 & 2.8 & $5.7^{c}$ & 1.6 & 19 \\
\hline SV-2 & 0.66 & 1.5 & 12.9 & 19.8 & 16.1 & 45 \\
\hline SV-3 & 0.70 & 1.8 & 5.3 & 17.3 & 7.8 & 31 \\
\hline$S V-4^{b}$ & 0.70 & 1.8 & 5.3 & 12.2 & 7.8 & 39 \\
\hline$S V-5$ & 0.73 & 2.4 & 3.8 & 8.8 & 7.7 & 47 \\
\hline
\end{tabular}


Table 6 . Selected benthic total oxygen uptake rates from Arctic, temperate and tropical areas. The values cover a wide span of geographic and seasonal variation, but reflect typical rates for deeper shelf sediments

\begin{tabular}{|c|c|c|c|c|}
\hline $\begin{array}{l}\text { Water depth } \\
\text { (m) }\end{array}$ & 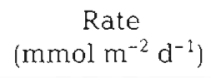 & Applied technique & Region & Source \\
\hline \multicolumn{5}{|c|}{ Arctic regions } \\
\hline $226-320$ & $3.2-11.9$ & Core incubation & Eastern Svalbard & Pfannkuche \& Thiel (1987) \\
\hline $19-54$ & $8.7 \cdot 19.2$ & Core incubation & Bering and Chukchi Seas & Grebmeier \& McRoy (1989) \\
\hline $170-240$ & $3.9 \cdot 11.2$ & Core incubation & Eastern Svalbard & Hulth et al. (1994) \\
\hline 40 & 17.8 & Core incubation & Eastern Greenland & Rysgaard et al. (1996) \\
\hline $30-52$ & $7.3-25.5$ & Core incubation & Bering and Chukchi Seas & Henriksen et al. (1993) \\
\hline 270 & 8.4 & In situ chamber & Off Newfoundland & Pomeroy et al. (1991) \\
\hline \multicolumn{5}{|c|}{ Temperate and tropical regions } \\
\hline $60-80$ & $4.6-9.9$ & Core incubation & NW Mediterranean & Tahey et al. (1994) \\
\hline $190-695$ & $11.8-16.1$ & In situ chamber & Skagerrak & Canfield et al. (1993) \\
\hline $70-255$ & $1.8-11.3$ & Core incubation & Eastern Canada & Grant et al. (1991) \\
\hline $86-185$ & $4.1-7.3$ & Core incubation & Washington shelf & Pamatmat (1973) \\
\hline $29-33$ & $8.8-10.5$ & Core incubation & Kattegat & Rasmussen \& Jørgensen (1992) \\
\hline $42-53$ & $7.9-13.8$ & Core incubation & Western Costa Rica & Thamdrup et al. (1996) \\
\hline $85-225$ & $5.2-18.3$ & In situ chamber & NE Pacific & Devol \& Christensen (1993) \\
\hline $115-222$ & $4.8-16.5$ & In situ chamber & Washington shelf & Archer \& Devol (1992) \\
\hline
\end{tabular}

Summing the efflux of $\mathrm{NO}_{3}{ }^{-}, \mathrm{NH}_{4}{ }^{+}$and $\mathrm{N}_{2}$, and comparing this to the efflux rate of $D I C$, the $C: N$ ratio of the total effluxing solutes varied from 7.5 to 13.6 . This range was observed for both laboratory and in situ results. Measurements carried out around Svalbard by Blackburn et al. (1996) resulted in average $\sum N$ effluxes of $1.07 \mathrm{mmol} \mathrm{m} \mathrm{m}^{-2} \mathrm{~d}^{-1}$, a value which is comparable to ours; however, they also showed that DON (dissolved organic nitrogen) accounted for approximately $80 \%$ of the $\Sigma N$ efflux. The observation was explained by a presumed degradation of a recent deposit of fresh organic material, where the majority of $\mathrm{N}$ left the sediment-water interface as DON. Our flux measurements of DIN and rates of denitrification were significantly higher than those of Blackburn et al. (1996); however, their investigations were performed in July 1991, and the discrepancy could be related to seasonal variations, with degradation of more fresh organic material during the summer as compared to the end of September when our data were obtained.

The primary production and thereby the sedimentation around Svalbard undergoes large seasonal variations, typically with a distinct bloom during spring and relatively high fluctuating values during summer which level off in August-September, whereafter sedimentation rates remain non-detectable until the following spring (Wassmann \& Slagstad 1993). Measurements in a NE Greenland fjord have demonstrated how settling of a summer bloom immediately stimulated benthic mineralization, and that after rapid degradation mineralization rates returned to their low basic level and remained low from August onward, through the rest of the season (Rysgaard et al. 1998). Our exchange measurements at the end of September neither reflect a maximum nor a minimum, but more likely an intermediary value, which in that sense approach the yearly average. There are no good measurements of primary production for the fjords investigated in this study, but an estimate of $150 \mathrm{~g} \mathrm{C} \mathrm{m}^{-2} \mathrm{yr}^{-1}$ for the area has been suggested (Eilertsen et al. 1989, Sakshaug \& Slagstad. 1992). Assuming that our mineralization rates reflect the yearly average, we calculated that 25 to $58 \%$ of the water column production was mineralized in the sediment. However, sediment focusing in fjords, especially those of Svalbard (Reigstad \& Wassmann 1996), makes it difficult to construct a carbon budget without more site-specific data.

\section{Carbon and nitrogen preservation in the fjords of Svalbard}

After diagenesis has been completed, the remaining refractory organic carbon is permanently buried. Assuming that carbon oxidation was generally completed at $19 \mathrm{~cm}$ sediment depth, as indicated by sulfate reduction profiles in the same sediments (Sagemann et al. 1998), and applying the approach described by Canfield (1994), the burial of refractory carbon could be calculated. This approach is based on the simple equation $\% \mathrm{C}$ preserved $=[\mathrm{C}$ burial flux $/$ depositional flux) $\times 100$. The carbon burial flux, as calculated from the ${ }^{210} \mathrm{~Pb}$ accumulation rates and the organic carbon content at a depth of $19 \mathrm{~cm}$, was in the range 1.6 to $16.1 \mathrm{mmol} \mathrm{C} \mathrm{m}^{-2} \mathrm{~d}^{-1}$ (Table 5). The depositional flux was calculated as the sum of the burial flux and the in situ DIC release. Carbon burial was thereby calculated to account for 31 to $47 \%$ of the carbon settling 


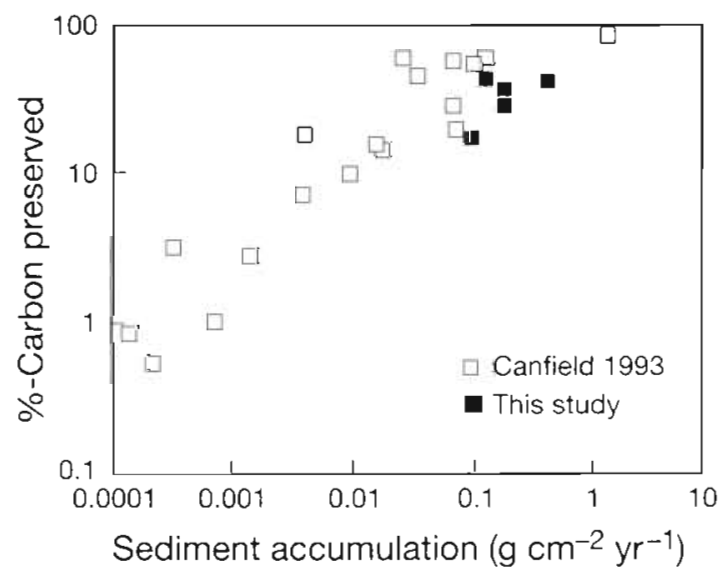

Fig. 10. Carbon preservation as a function of sediment accumulation rates from a variety of coastal sediments (ㅁ) and from the Svalbard stations investigated in this study Partly redrawn from Canfield (1994)

in these sediments (Table 5). Carbon preservation at $\mathrm{SV}-1$ could only be calculated on the basis of laboratory data and equaled $19 \%$ of the carbon deposited. The calculated values are well within the range expected for normal marine sediments with the same sediment accumulation rate (Fig 10). These calculations indicate that mineralization in Arctic sediments is at least as efficient as in comparable temperate or tropical shelf sediments.

As discussed above, our in situ mineralization rates probably represent an intermediary value between the yearly maximum and minimum. If our rates overestimate the yearly average the carbon burial percentage will be correspondingly underestimated. On the other hand the carbon burial percentage may be overestimated to the extent that our estimates for sediment accumulation are affected by bioturbation. We therefore consider the carbon preservation values presented in Table 5 as reasonable estimates for the investigated sediments.

In temperate coastal waters which are exposed to seasonal changes in temperature it is generally observed that low temperatures decrease the rates of biologically mediated processes (e.g. Abdollahi \& Nedwell 1979, King \& Nedwell 1984, Thamdrup et al. 1998). However, our measurements indicate that both the efficiency and the rates of benthic mineralization in the permanently cold sediments of Svalbard are similar to values obtained in temperate and tropical sediments. In addition, investigations on polysaccharide hydrolysis in the same sediments indicated a relatively higher turnover rate at these low temperatures, and it appeared that extracellular enzymatic hydrolysis did not limit the turnover of organic carbon in the sediments of Svalbard (Arnosti et al. 1998). Finally, the direct enumeration of bacteria and flagellates in the investigated sediments resulted in values that were no higher than what has been reported for temperate shelf sediments at comparable water depths (U. Berninger unpubl. res.); the efficient benthic mineralization is therefore not caused by higher population densities of microorganisms. These observations and our in situ measurements indicate that Arctic sediments contain a benthic community that is well adapted to the constant cold environment and that degrades organic material as efficiently as communities which experience significantly higher temperatures.

Acknowledgements. We thank the captain and crew of the RV 'Jan Mayen' for their assistance and for creating an enjoyable atmosphere on board and Jan Einer Hansen for tirelessly solving practical problems in connection with the cruise. Soren Rysgaard and colleagues are thanked for measuring the ${ }^{15} \mathrm{~N}$ samples and some of the nutrient samples. Per Hall and colleagues are thanked for assistance during the coulometric measurements of DIC. This work was generously supported by the Max Planck Society. In the writing process R.N.G. was supported by the Commission of the European Community under the MAST III program 'MICROMARE', project no. 950029, and the Danish National Research Council (SNF); the support is gratefully acknowledged. D.E.C. was supported by the Danish National Research Council (SNF).

\section{LITERATURE CITED}

Abdollahi HA, Nedwell DB (1979) Seasonal temperature as a factor influencing bacterial sulfate reduction in a saltmarsh sediment. Microb Ecol 5:73-79

Antoine D, Andre JM, Morel A (1996) Ocean primary production 2. Estimation at global scale from satellite (coastal zone color scanner) chlorophyll. Global Biogeochem Cycles $10: 57-69$

Archer D, Devol A (1992) Benthic oxygen fluxes on the Washington shelf and slope: a comparison of in situ microelectrode and chamber flux measurements. Limnol Oceanogr 37:614-629

Archer D, Emerson S, Smith CR (1989) Direct measurements of the diffusive sublayer at the deep sea floor using microelectrodes. Nature 340:623-626

Arnosti C, Jorgensen BB, Sagemann J, Thamdrup B (1.998) Temperature dependence of microbial degradation of organic matter in marine sediments: polysaccharide hydrolysis, oxygen consumption, and sulfate reduction. Mar Ecol Prog Ser 165:59-70

Barnett PRO, Watson J, Connelly D (1984) A multiple corer for taking virtually undisturbed samples from shelf, bathyal and abyssal sediments. Oceanol Acta 7:399-408

Bender ML. Heggie DT (1984) Fate of organic carbon reaching the deep sea floor: a status report. Geochim Cosmochim Acta 52:751-765

Bender M, Martin W, Hess J, Sayles F, Ball L, Lambert C (1987) A whole-core squeezer for interfacial pore-water sampling. Limnol Oceanogr 32:1214-1225

Berger WH, Smetacek VS, Wefer G (1989) Ocean productivity and paleoproductivity - an overview. In: Berger WH, Smetacek VS, Wefer G (eds) Productivity of the ocean: present and past. John Wiley \& Sons, New York, p 1-34 
Berner RA (1980) Early diagenesis: a theoretical approach. Princeton University Press, Princeton, NJ

Blackburn TH (1987) Microbial food webs in sediments. In: SIeigh MA (ed) Microbes in the sea. Ellis Horwood, Chichester, p 39-58

Blackburn TH, Hall POJ, Hulth S, Landen A (1996) Organic$N$ loss by efflux and burial associated with low efflux of inorganic $\mathrm{N}$ and nitrate assimilation in Arctic sediments (Svalbard, Norway). Mar Ecol Prog Ser 141:283-293

Bower E. Hansen HA (1980) A salicylate-hypochlorite method. for determining ammonia in seawater. Can J Fish Aquat Sci 37:794-798

Braman RS, Hendrix SA (1989) Nanogram nitrite and nitrate determination in environmental and biological materials by Vanadium(III) reduction with chemiluminescence detection. Anal Chem 61:2715-2718

Brandes A, Devol. A.H (1995) Simultaneous nitrate and oxygen respiration in coastal sediments: evidence for discrete diagenesis. J Mar Res 53:771-797

Broecker WS, Peng TH (1974) Gas exchange rates between air and sea. Tellus 26:21-35

Broström B, Broström K (1991) Magnesium hydroxide precipitation as pre-enrichment procedure for inductively coupled plasma-atomic emission spectrometric analyses of natural waters. Geol Foren Stockholm Forhandl 113: $97-103$

Cai WJ. Sayles FL (1996) Oxygen penetration depths and fluxes in marine sediments. Mar Chem 52:123-131

Canfield DE (1989) Sulfate reduction and oxic respiration in marine sediments: implications for organic carbon preservation in euxinic environments. Deep-Sea Res 36:121-138

Canfield DE (1994) Factors influencing organic carbon preservation in marine sediments. Chem Geol 114: 315-329

Canfield DE, Jørgensen BB, Fossing $H$, Glud RN, Gundersen JK, Thamdrup B, Hansen JW, Nielsen LP, Hall POJ (1993) Pathways of organic carbon oxidation in three continental margin sediments. Mar Geol 113:27-40

Devol HA, Christensen JP (1993) Benthic fluxes and nitrogen cycling in sediments of the continental margin of the eastern North Pacific. J Mar Res 51:345-372

Eilertsen HC, Taasen JP, Weslawski JM (1989) Phytoplankton studies in the fjords of West Spitzbergen: physical environment and production in spring and summer. J Plankton Res 11:1245-1260

Glud RN, Forster S, Huettel M (1996) Influence of radial pressure gradients on solute exchange in stirred benthic chambers. Mar Ecol. Prog Ser 141:303-311

Glud RN, Gundersen JK, Jørgensen BB, Revsbech NP, Schulz HD (1994a) Diffusive and total oxygen uptake of deep-sea sediments in the eastern South. Atlantic Ocean: in situ and laboratory measurements. Deep-Sea Res 41:1767-1788

Glud RN, Gundersen JK, Revsbech NP, Jørgensen BB (1994b) Effects on the benthic diffusive boundary layer imposed by microelectrodes. Limnol Oceanogr 39:462-467

Glud RN, Gundersen JK, Revisbech NP, Jargensen BB, Huettel M (1995) Calibration and performance of the stirred flux chamber from the benthic lander Elinor. DeepSea Res 42:1029-1042

Grant J, Emerson CW, Hargrave BT, Shortle JL (1991) Benthic oxygen consumption on continental shelves off Eastern Canada. Cont Shelf Res 11:1083-1097

Grasshoff K, Erhardt M, Kremling K (1983) Methods of seawater analysis, 2nd edn. Verlag Chemie, Weinheim

Grebmeier JM, McRoy CP (1989) Pelagic-benthic coupling on the shelf of northern Bering and Chukchi Seas. III. Benthic food supply and carbon cycling. Mar Ecol Prog Ser
$53: 79-91$

Gundersen JK, Jørgensen BB (1990) Microstructure of diffusive boundary layers and the oxygen uptake of the sea floor. Nature 345:604-607

Hall POJ, Aller RC (1992) Rapid, small-volume, flow injection analysis for $\sum \mathrm{CO}_{2}$ and $\mathrm{NH}_{4}{ }^{+}$in marine and freshwaters. Limnol Oceanogr 37:1113-1119

Hall POJ, Anderson LG, Holby O, Kollberg S, Samuelsson MO (1990) Chemical fluxes and mass balances in a marine fish cage farm. I. Carbon. Mar Ecol Prog Ser 61:61-73

Henriksen KT, Blackburn H, Lomstein BA, McRoy CP (1993) Rates of nitrification, distribution of nitrifying bacteria and inorganic $\mathrm{N}$ fluxes in the northern Bering-Chuckchi shelf sediments. Cont Shelf Res 13:629-651

Høpner-Petersen G (1989) Benthos an important compartment in northern aquatic ecosystems. In: Rey L, Alexander $\mathrm{V}$ (eds) Proc 6th Cont Com Artique Int. Brill, Leiden, p $162-178$

Huettel M. Gust G (1992a) Solute release mechanisms from confined sediment cores in stirred benthic chambers and flume flows. Mar Ecol Prog Ser 82:1,87-197

Huettel M, Gust G (1992b) Impact of bioroughness on interfacial solute exchange in permeable sediments. Mar Ecol Prog Ser 89:253-267

Hulth S, Blackburn TH, Hall POJ (1994) Arctic sediments (Svalbard): consumption and microdistribution of oxygen. Mar Chem 46:293-316

Hulth S, Hall POJ, Blackburn TH, Landen A (1996) Arctic sediments (Svalbard): porewater and solid phase distributions of C, N, P and Si. Polar Biol 16:447-462

Johnson KM, Sieburth JM, Williams PJL, Brändström L (1987) Coulometric total carbon dioxide analysis for marine studies: automation and calibration. Mar Chem 21:117-133

Jones MN (1984) Nitrate reduction by shaking with cadmium. Water Res 18:643-646

Jorgensen BB (1977) The sulfur cycle of a coastal marine sediment (Limfjorden, Denmark). Limnol Oceanogr 5: $814-832$

King D, Nedwell DB (1984) Changes in the nitrate-reducing community of an anaerobic saltmarsh sediment in response to seasonal selection by temperature. J Gen Microbiol 130:2935-2941

Li YH, Gregory S (1974) Diffusion of ions in deep-sea sediments. Geochim Cosmochim Acta 38:703-714

Middelburg JJ, Soetaeert K, Herman PMJ (1996) Evaluation of the nitrogen isotope-pairing method for measuring benthic denitrification: a simulation analysis. Limnol Oceanogr 41:1839-1844

Nielsen LP (1992) Denitrification in sediments determined from nitrogen isotope pairing. FEMS Microb Ecol 86 $357-362$

Nielsen LP, Risgaard-Petersen N, Rysgaard S Blackburn TH (1996) Reply to the note of Middelburg et al Limnol Oceanogr 41:1845-1846

Pamatmat MM (1973) Benhic community metabolism on the continental terrace and in the deep sea in the North Pacific. Int Rev Ges Hydrobiol 58:345-368

Pfannkuche $O$, Thiel $H$ (1987) Meiobenthic stocks and benthic activity on the NE-Svalbard Shelf and in the Nansen Basin. Polar Biol 7:253-266

Piepenburg D, Blackburn TH, von Dorrien CF, Gutt J, Hall POJ, HuIth S, Kendall MA, Opalinski KW, Rachor E, Schmid MK (1995) Partitioning of benthic community respiration in the Arctic (northwestern Barents Sea). Mar Ecol. Prog Ser 118:199-213

Pomeroy LR, Wiebe WJ, Deibel D. Thompson RJ, Rowe GT. Pakulski JD (1991) Bacterial response to temperature and 
substrate concentration during the Newfoundland spring bloom. Mar Ecol Prog Ser 75:143-159

Rasmussen H, Jørgensen BB (1992) Microelectrode studies of seasonal oxygen uptake in a coastal sediment: role of molecular diffusion. Mar Ecol Prog Ser 81:289-303

Reigstad M, Wassmann P (1996) Importance of advection for pelagic-benthic coupling in north Norwegian fjords. Sarsia 80:199-224

Revsbech NP (1989) An oxygen microelectrode with a guard cathode. Limnol Oceanogr 34:474-478

Revsbech NP, Jørgensen BB (1986) Microelectrodes and their use in microbial ecology. In: Marshall KC (ed) Advances in microbial ecology, Vol 9. Plenum Press, New York, p 293-352

Risgaard-Petersen N, Rysgaard S (1995) Nitrate reduction in sediments and waterlogged soil measured by ${ }^{15} \mathrm{~N}$ techniques. In: Alef $\mathrm{K}$ (ed) Methods in applied soil microbiology and biochemistry. Academic Press, London, p $279-288$

Rysgaard S, Finster K, Dahlgaard H (1996) Primary production, nutrient dynamics and mineralisation in a northeastern Greenland fjord during the summer thaw. Polar Biol 16:497-506

Rysgaard S, Thamdrup B, Risgaard-Petersen N, Fossing $\mathrm{H}$, Berg P, Christensen PB, Dalsgaard T (1998) Seasonal carbon and nutrient mineralization in a high-Arctic coastal marine sediment, Young Sound, Northeast Greenland. Mar Ecol Prog Ser (in press)

Sagemann J, Jørgensen BB, Greff O (1998) Temperature dependence and rates of sulfate reduction in cold sediments of Svalbard, Arctic Ocean. Geom J 15:85-100

Sakshaug E, Slagstad D (1992) Sea ice and wind: effects on primary productivity in the Barents Sea. Atmos Ocean 30 : 579-591

Sambrotto RN, Goering JJ, McRoy CP (1984) Large yearly production of phytoplankton in the Western Bering Strait. Science 225:1147-1150

Smith KL Jr, Hinga KR (1983) Sediment community respiration in the deep sea. In: Rowe GT (ed) The sea, Vol 8. John Wiley and Sons, New York, p 331-370

Smith KL Jr, Laver MB, Brown NO (1983) Sediment community oxygen consumption and nutrient exchange in the central

Editorial responsibility: Tom Fenchel (Contributing Editor), Helsinger, Denmark and eastern North Pacific. Limnol Oceanogr 28:882-898

Strickland JD, Parsons TR (1972) A practical handbook of seawater analysis, 2nd edn. Bull Fish Res Board Can 167

Subba Rao DV, Platt T (1984) Primary production of Arctic waters. Polar Biol 3:191-201

Tahey TM, Duineveld GCA, Berghuis EM, Helder W (1994) Relation between sediment-water fluxes of oxygen and silicate and faunal abundance at continental shelf, slope and deep-water stations in northwest Mediterranean. Mar Ecol Prog Ser 104:119-130

Thamdrup B, Canfield D, Ferdelman T, Glud RN, Gundersen JK (1996) A biogeochemical survey of the anoxic basin Golfo Dulche, Costa Rica. Rev Biol Trop 44:19-33

Thamdrup B, Fleischer S (1998) Temperature dependence of oxygen respiration, nitrogen mineralization, and nitrification in Arctic sediments. Aquat Microb Ecol 15:191-199

Thamdrup B, Fossing H, Jorgensen BB (1994) Manganese, iron and sulfur cycling in a coastal marine sediment, Aarhus Bay, Denmark. Geochim Cosmochim Acta 58: 5115-5129

Thamdrup B, Hansen JW, Jørgensen BB (1998) Temperature dependence of aerobic respiration in a coastal sediment. FEMS Micrab Ecol 25:189-200

Uliman WJ, Aller RC (1982) Diffusion coefficients in nearshore marine sediments. Limnol Oceanogr 27:552-556

Wassmann P (1990) Relationship between primary and export production in the boreal coastal zone of the North Atlantic. Limnol Oceanogr 35:464-471

Wassmann P, Peinert R, Smetacek V (1991) Patterns of production and sedimentation in the boreal and polar Northeast Atlantic. In: Sakshaug E, Hopkins CEE, Øritsland NA (eds) Proceedings of the Pro Mare Symposium on Polar Marine Ecology, Trondheim. Polar Res 10:209-228

Wassmann P, Slagstad D (1993) Seasonal dynamics of particulate carbon flux in the Barents Sea. Polar Biol 13: $363-372$

Wollast R (1991) The coastal organic carbon cycle: fluxes, sources and sinks. In: Mantoura RFC, Martin JM, Wollast $\mathrm{R}$ (eds) Ocean margin processes in global change. John Wiley \& Sons, New York, p 365-381

Zenkevitch LA (1963) Biology of the seas of USSR. George Allen \& Unwin Ltd, London

Submitted: March 19, 1998; Accepted: July 21, 1998

Proofs received from author(s): October 12, 1998 